\title{
STUDY OF EFFICIENCY OF OIL REMOVAL OF WATER PRODUCED (PETROBRAS RN/CE) USING ADSORVENT
}

\section{ESTUDO DA EFICIÊNCIA DA REMOÇÃO DE ÓlEO DA ÁGUA PRODUZIDA (PETROBRAS RN/CE) USANDO ADSORVENTE}

\author{
I. A., SÁ $^{1}$, A.L. S. COSTA ${ }^{2}$, A. K. C. OLIVEIRA ${ }^{3}$ and E. M. F. SANTOS ${ }^{4}$
}

Federal Institute of Rio Grande do Norte, Natural Resources, Natal, Rio Grande do Norte, Brazil

\footnotetext{
* Isamar Alves de Sá. Institute of Rio Grande do Norte, Department of Natural Resources, Natal,Rio Grande do Norte, Brasil, Phone: +55 84987266164

e-mailisa_qui@yahoo.com.br(I.A.SÁ).
}

\begin{tabular}{l} 
A R T I C L E I N F O \\
\hline Article history: \\
Received 2018-10-15 \\
Accepted 2018-12-23 \\
Available online 2019-04-25 \\
p a l a vra $s$ - $h a v e$ \\
Água Produzida \\
Adsorção \\
Areia de Praia \\
Carvão Ativado \\
Casca de coco in natura \\
$k$ e y $w$ o $d s$ \\
Produced Water \\
Adsorption \\
Beach Sand \\
Active Charcoal \\
Coconut Shell in Natura
\end{tabular}

\begin{abstract}
A B S T R A C T
The management of water produced with oil $(P W)$ is a major challenge for oil companies due to high volume generation and chemical complexity. It is necessary to treat it in order to minimize harmful effects to the environment through an appropriate treatment, allowing its reuse and, consequently, causing the least possible damage to the processes in which it will be used. The samples of contaminated water passed through three adsorbents: activated carbon $(1.18 \mathrm{~mm})$, beach sand $(2 \mathrm{~mm})$ and coconut shell in natura. The objective of this article is to compare the efficiency of the adsorption process in water contaminated with oil. The results showed the following efficiencies: $82 \%$ in the removal of turbidity when using the active charcoal, $95.90 \%$ in the removal of turbidity when using the sand of the beach and $38.38 \%$ in the removal of turbidity when using the coconut shell in natura.
\end{abstract}

\begin{abstract}
R E S U M O
O gerenciamento da água produzida com óleo $(P W)$ é um grande desafio para as empresas petrolíferas devido à alta geração de volumes e complexidade química. É necessário tratá-la a fim de minimizar os efeitos nocivos ao ambiente través de um tratamento adequado, permitindo sua reutilização e, consequentemente, causando o menor dano possível aos processos em que será utilizado. As amostras de água contaminada passaram por três adsorventes: carvão ativado $(1,18 \mathrm{~mm})$, areia de praia $(2 \mathrm{~mm})$ e casca de coco in natura. $O$ objetivo deste artigo é comparar a eficiência do processo de adsorção em águas contaminadas com óleo. Os resultados mostraram as seguintes eficiências: $82 \%$ na remoção de turbidez ao utilizar o carvão ativo, 95,90\% na remoção de turbidez ao utilizar a areia da praia e 38,38\% na remoção de turbidez ao utilizar a casca de coco in natura.
\end{abstract}

\section{INTRODUCTION}

During the production of oil and gas is common to the joint production of water, called produced water, production water or process water. This fluid is composed of the water of the reservoir itself and the seawater injected into the field, which serves both to maintain the reservoir pressure and to increase the secondary recovery of the oil, emphasizing that in mature fields the volume of water produced can be 10 times greater than the volume of oil produced. According to Neff (2011), the amount of water produced in the oil production activity varies according to the characteristics and age of the field, and the more mature reservoirs are responsible for generating the largest quantities of this effluent. The water produced is generated as a by-product of the production of oil and gas during the process of separation by which these fluids pass, called primary process for transformation into commercial products. The alternatives 
usually adopted for its destiny are the discard, the injection and the reuse. In all cases, there is a need for specific treatment in order to meet the environmental, operational or production demands that will use it as raw material.

One of the objectives of the treatment is the removal of oil, which may be present in the water under free, emulsified (or emulsified) forms and dissolved. The search for new PW treatment processes is particularly important when oil production has increased considerably over the years (Freitas et al., 2015). In the years 2001 to 2011, world oil production increased by $12 \%$, from 74.77 million barrels per day to 83.58 million barrels per day.

In Brazil, in the same period, the increase was even more significant: it surpassed $60 \%$, from 1.34 million to 2.19 million barrels a day (BP, 2012). Brazilian production is more concentrated in the states of Rio de Janeiro and Espírito Santo, which account for approximately $74 \%$ and $15 \%$ of the total, respectively (ANP, 2012). According to Fraser et al. (2009) because of their chemical complexity, discards of produced water may be responsible for altering the quality of seawater, increasing the concentration of pollutants in the water column and contaminating the marine sediment, including causing damage to the benthic community and its habitat and indirectly to fish.

In descartes on shore, the composition of this effluent can lead to irreversible damages to more sensitive water bodies, soil contamination and atmospheric emissions (IFC, 2007). For these reasons and allied to large volumes of generation, the water produced is perhaps one of the most relevant environmental aspects of all oil exploration and production activity. In order to comply with the standards of the Conselho Nacional do Meio Ambiente (CONAMA 357/430), the organization responsible for regulating Brazilian environmental laws, conventional methods such as gravitational separation, flotation and hydrocyclones are common.

However, these methods may not demonstrate adequate efficiency for emulsified or dissolved oil droplets and, therefore, other technologies are employed, emphasizing that the water produced has a high potential for pollution, due to its rich composition, especially in chemicals and dissolved oil, a series of treatments are necessary in order to minimize or extinguish the harmful effects of these constituents. Among the treatments used, the adsorption process becomes a treatment with great potential. Many studies have proven the efficiency of these adsorbents for the treatment of water and effluents contaminated by oil, heavy metals and other toxic substances. According to Curbelo (2002) the main components of an adsorption process are: fluid, surface (a porous solid) and the substance removed by the surface.

According to Cavalcante (2012), the adsorption process occurs by a mass transfer where the fluid phase is naturally concentrated on a generally solid surface. According to CONAMA (393, 2007), contaminated effluents must comply with the arithmetic mean concentration of $29 \mathrm{mg} / \mathrm{L}$ monthly, with a daily value of $42 \mathrm{mg} / \mathrm{L}$. In this sense, in the present work, the adsorption method was used using different types of adsorbents that have chemical affinity with the petroleum or grain structure well arranged to its storage to evaluate, within the range studied, the best oil removal.

\section{METHODS}

At first, bibliographical and scientific studies on water produced and adsorption were carried out. After that, the following parameters were analyzed: $\mathrm{pH}$ (digital $\mathrm{pH}$ meter), density (Shimadzu analytical balance pycnometry), electrical conductivity (portable conductivity meter MOD.LUCA $150 \mathrm{MC} / \mathrm{P}$ ) and turbidity (turbidimeter - Fast Tracker). Then, the following adsorbent materials were selected: active charcoal with a mean particle size of $-1.18 \mathrm{~mm}$; beach sand-2mm - (Praia do Forte - Natal/RN) and coconut shell in natura $(2 \mathrm{~cm})$; materials chosen because of their compositions have petroleum affinity or storage characteristics, as in the case of beach sand. Thus, the treatment for the removal of the effluents in the PW was started.

The samples of PW (real) were assigned by PETROBRAS, RN/CE. In the case of the adsorbents, the coconut shell in natura passed through the knife mill (fragmented to $2 \mathrm{~cm}$ fibers); the active carbon was purchased in the Natal/RN trade and the beach sand was collected at Praia do Forte, in Natal/RN. The samples were oven dried at $105^{\circ} \mathrm{C}$.

\subsection{Experimental Procedure}

The procedure was initiated with the withdrawal of 240 $\mathrm{mL}$ of PW (raw water), $(\mathrm{m} / \mathrm{cm})$, density $(\mathrm{g} / \mathrm{mL})$ and turbidity (NTU). The filter paper was then placed in the simple laboratory funnel, base of the carrier, an erlenmeyer for reception of the treated samples, shown in Figure 1. The determined amount of adsorbent was weighed using the analytical balance, depositing it on the filter (in which a blank test was performed to ensure no chemical interference in the results, functioning only as a support of the adsorbents) and, soon after, the measured water volume was inserted. $30 \mathrm{~min}$ was standardized to observe the efficiency of the treatment in that time interval and at the end of the period the treated water turbidity was measured. This method was repeated in triplicate with the following masses: 5 $\mathrm{g}, 30 \mathrm{~g}, 60 \mathrm{~g}, 90 \mathrm{~g}, 120 \mathrm{~g}$ and $140 \mathrm{~g}$; with the three types of adsorbents chosen.

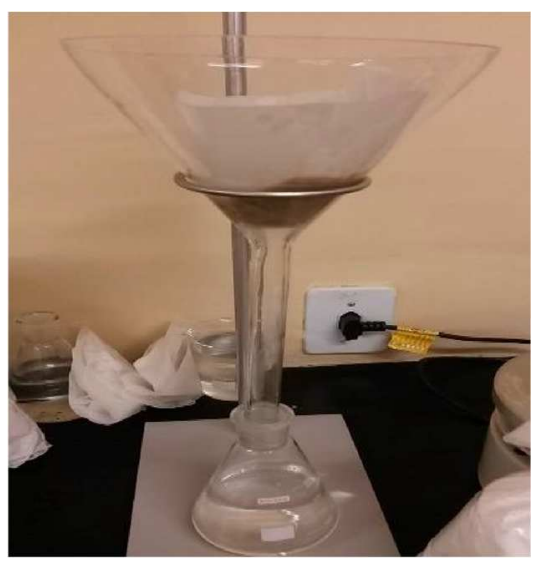

Figure 1: Adsorption Process 


\section{RESULTS AND DISCUSSION}

Initially, the raw water submitted to the adsorption process obtained the following results of physical-chemical analyzes (Table 1):

Table 1: Result of raw water parameters

\begin{tabular}{cccc}
\hline $\mathbf{p H}$ & $\begin{array}{c}\text { Electric } \\
\text { Conductivity in } \\
\mathbf{2 5}^{\circ} \mathbf{C}(\mathbf{m s} / \mathbf{c m})\end{array}$ & $\begin{array}{c}\text { Turbidity } \\
\text { (NTU) }\end{array}$ & $\begin{array}{c}\text { Density } \\
(\mathbf{g} / \mathbf{m L})\end{array}$ \\
\hline 7.00 & 8.55 & 35.20 & 1.00 \\
\hline
\end{tabular}

After the treatment of the water with the three adsorbents, in their different masses, the same parameter readings were made in the treated water for comparison

Table 2: Results of the parameters of the water treated by the three adsorbents

\begin{tabular}{|c|c|c|c|c|}
\hline $\begin{array}{l}\text { Mass } \\
\text { a (g) }\end{array}$ & $\begin{array}{c}\mathrm{pH} \\
\text { Electrical }\end{array}$ & $\begin{array}{c}\text { conductivity } \\
(\mathrm{ms} / \mathrm{cm} \text { até } \\
\left.25^{\circ} \mathrm{C}\right)\end{array}$ & $\begin{array}{c}\text { Turbidity } \\
\text { (NTU) }\end{array}$ & $\begin{array}{c}\text { Density } \\
(\mathrm{g} / \mathrm{mL})\end{array}$ \\
\hline \multicolumn{5}{|c|}{ Results treated water - coconut shell $(2 \mathrm{~cm})$} \\
\hline 5 & 7.01 & 18.87 & 35.11 & 1.00 \\
\hline 30 & 6.89 & 22.80 & 21.69 & 1.00 \\
\hline 60 & 7.02 & 29.5 & 23.31 & 0.99 \\
\hline 90 & 6.99 & 32.9 & 24.61 & 1.00 \\
\hline 120 & 6.95 & 26.1 & 24.83 & 1.00 \\
\hline 140 & 6.99 & 26.1 & 24.83 & 1.00 \\
\hline \multicolumn{5}{|c|}{ Results treated water - coal granulometry $1.18 \mathrm{~mm}$} \\
\hline 5 & 7.00 & 8.87 & 24.40 & 0.98 \\
\hline 30 & 7.22 & 8.80 & 6.33 & 0.99 \\
\hline 60 & 7.35 & 9.10 & 21.33 & 0.99 \\
\hline 90 & 6.99 & 8.89 & 28.86 & 1.00 \\
\hline 120 & 6.35 & 8.99 & 30.21 & 1.00 \\
\hline 140 & 6.99 & 8.90 & 30.62 & 1.00 \\
\hline \multicolumn{5}{|c|}{ Results treated water - beach sand (grain size $2 \mathrm{~mm}$ ) } \\
\hline 5 & 7.00 & 13.71 & 26.08 & 0.97 \\
\hline 30 & 7.30 & 13.40 & 18.76 & 0.98 \\
\hline 60 & 7.35 & 14.17 & 21.33 & 1.00 \\
\hline 90 & 7.38 & 14.59 & 1.44 & 1.01 \\
\hline 120 & 7.39 & 17.36 & 5.54 & 1.00 \\
\hline 140 & 7.26 & 17.00 & 23.944 & 1.01 \\
\hline
\end{tabular}

According to Table 2, the $\mathrm{pH}$ of the treated water remained practically constants with use of all adsorbents; there was increase of salinity with the use of coconut shell in natura and beach sand and the few densities were altered in the water treated with the three adsorbents; the lowest results for treated water turbidity were observed with the use of adsorbent beach sand in 90 and $120 \mathrm{~g}$ in the studied range. The greater turbidity of the exit was verified with the use of the coconut shell in natura, probably for its high amount of water and lignin, having more affinity to the alcohols, than to the hydrocarbons, presenting the worst result of removal of the polluting oil. The high turbidities of the active charcoal (which has in its carbonic composition chemical affinity with the petroleum) are justified by the low surface area of the adsorbent, given its medium granulometry $(1.18 \mathrm{~mm})$, making it difficult to interact with the contaminant oil and reducing removal efficiency.

Then, the oil removal efficiency calculations were performed for the adsorbent materials (activated carbon medium, beach sand and coconut shell in natura), in their different masses used: The results were obtained according to Table 3.

Table 3: Results of turbidity removal

\begin{tabular}{llll}
\hline $\begin{array}{c}\text { Mass of } \\
\text { adsorbent } \\
\text { (g) }\end{array}$ & $\begin{array}{c}\text { Granulate } \\
\text { d coal }\end{array}$ & $\begin{array}{c}\text { Beach } \\
\text { sand }\end{array}$ & $\begin{array}{c}\text { Coconut } \\
\text { shell in } \\
\text { natura }\end{array}$ \\
\hline 5 & 30.68 & 25.90 & 0.27 \\
30 & 82.00 & 46.70 & 38.38 \\
60 & 39.40 & 68.51 & 33.78 \\
90 & 18.00 & 95.90 & 30.08 \\
120 & 14.17 & 84.25 & 29.46 \\
140 & 13.00 & 68.00 & 29.46 \\
\hline
\end{tabular}

According to the values obtained in Table 3, it was observed that the highest percentage of removal $(95.9 \%)$ of the oil occurred with the use of $90 \mathrm{~g}$ of sand, within the range studied.

Increasing the sand mass, from $90 \mathrm{~g}$, there was a decrease in the removal process. In that the lowest percentage of removal of this adsorbent occurred in the use of $5 \mathrm{~g}$ of sand $(25.9 \%)$, as expected from the planning. The natural characteristics of the sand in storing the hydrocarbons in its pores, made that its efficiency was confirmed.

Analyzing the values obtained in the use of the coal as adsorbent material, it was observed its greater percentage of removal $82 \%$, with the use of $30 \mathrm{~g}$ of the adsorbent. For the other analyzed mass values of coal there was a decrease in the removal process, possibly due to the fact that the average coal used has its surface area reduced by the size of the grains; the efficiency would certainly increase with the use of a smaller particle size of the active carbon. Thus, in spite of presenting hydrocarbon affinity compositional chemistry, showing the apolarity, the results of oil removal in the water, for the study carried out, were not good with the use of medium carbon, being still lower in percentage than the other adsorbents for the range studied.

The values obtained in the adsorption process for the fragmented in natura coconut shell were closer to each other, but still, there was a low removal of petroleum that is apolar (about $35 \%$ ), according to table 03 , being the lowest removal value when $5 \mathrm{~g}$ of the adsorbent was used. This can be explained by the high content of lignin and cellulose in the coconut shell in natura (Cabral et al, 2017), favoring the production of ethanol than its use for the removal of hydrocarbons. Therefore, the beach sand showed better results of removal of contaminating oil in the water produced from the well, in relation to the study done. 


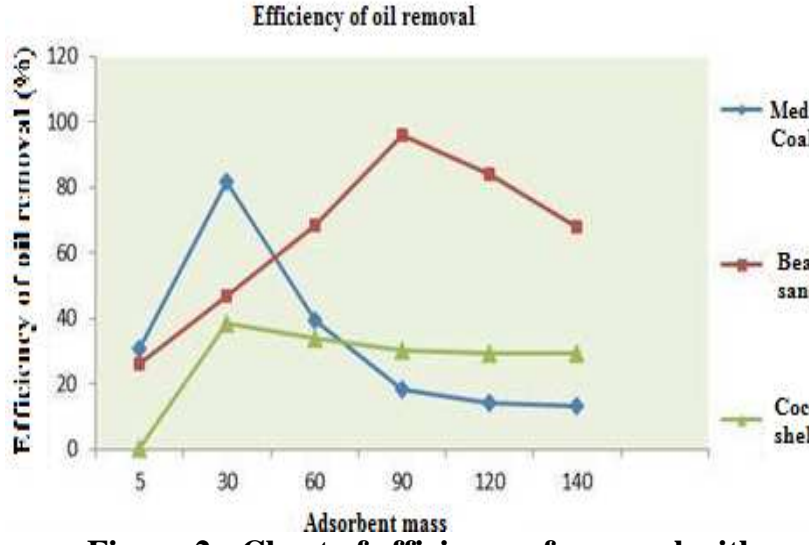

Figure 2 - Chart of efficiency of removal with medium granular coal, beach sand and coconut shell in natura cut.

Figure 2 shows the removal efficiencies for the three adsorbents studied, demonstrating that in the first masses (from 5 to $60 \mathrm{~g}$ ) there is advantage of removal for the coal, in relation to the other adsorbents; the beach sand presents, in this range, secondly, removal better than the bark of coconut in natura. It is observed that from $60 \mathrm{~g}$, there is a greater efficiency of oil removal with beach sand, in all the points studied; the average coal, from this point, has a lower removal efficiency, being close to, but still below, the removal of the coconut shell in natura and the beach sand, which stands out as the best adsorbent for oil removal, in the study carried out.

\section{CONCLUSIONS}

Based on bibliographical, scientific and laboratory tests, the efficiency and efficacy of the sand and coal adsorbents studied were tested. Although Coal presented satisfactory results in point $2(82 \%)$; it becomes feasible and more effective the use of the Beach Sand, as besides presenting more satisfactory values of adsorption also has a lower cost and an easy access making it more suitable for adsorbent purposes, since it does not solubilize in water and presents considerable oil removal results.
CONAMA, CONSELHO NACIONAL DO MEIO AMBIENTE - Resolução no 39379. Accessed on: 03/14/2018

CURBELO, F. D. da S. Estudo da remoção de óleo em águas produzidas na indústria de petróleo, por adsorção em coluna utilizando a vermiculita expandida e hidrofobizada. 2002, 2p. Dissertação em Engenharia Química, Universidade Federal do Rio Grande do Norte, Programa de Pós-Graduação em Engenharia Química. Natal/RN. Coel

RASER, G. S.; ELLIS, J. The Canada- Newfoundland Atlantic Accord Implementation Act: Transparency of the environmental management of the offshore oil and gas industry. Marine Policy, v. 33, p. 312-316, 2009.

FREITAS, A. G. B. et al. Equipamentos para tratamento de água produzida na indústria de petróleo: aspecto temporal. Revista Geintec, Vol. 5, p.2316- 2325, 2015.

IFC.Environmental, health and safety guidelines for onshore oil and gas development. International Finance

Corporation - World Bank Group, p. 27, 2007.

MOTTA, A. R. P. et al. Tratamento de água produzida de petróleo para remoção de óleo por processos de separação por membranas: revisão. Eng Sanit Ambient, v. 18, p. 15-26, 2013.

NEFF, J. E.M. Produced Water: Environmental Risks and Advances in Mitigation Technologies. Springer Science, 2011.

ONOJAKE,C.; ABANUM, U.I. Evaluation and management of produced water from selected oil fields in Niger Delta, Nigeria. Archives of Applied Science Research, v. 4, p. 39-47, 2012. Viçosa, MG, 2004.

\section{R E F E R E N C E S}

ANP, AGÊNCIA NACIONAL DO PETRÓLEO, GÁS NATURAL E BIOCOMBUSTÍVEIS - Boletim da Produção de Petróleo e Gás Natural. Accessed on: 02/21/2018.

BP, BRITISH PETROLEUM - Statistical Review of World Energy. Accessed on: 04/14/2018.

CABRAL, M. M. S.; ABUD, A. K.S.; ROCHA, M.S.R.S. Composição da fibra da casca de coco verde in natura e após pré-tratamentos químicos. ENGEVISTA V.19, P 99-108, janeiro 2017.

CAVAlvante JR, C. Separação de Misturas por Adsorção: dos fundamentos ao processamento em escala comercial. Revista Dae, p. 22, 1998. 